\title{
Execution of a Sentence - an Independent Stage of Criminal Proceedings
}

\section{VYACHESLAV B. SHABANOV}

Belarusian State University, Minsk, Republic of Belarus

ORCID: https://orcid.org/0000-0002-5796-3727, e-mail: lawcrim@bsu.by

\section{LYUDMILA YU. BUDANOVA}

Pskov Branch of the Academy of FSIN Russia, Pskov, Russian Federation ORCID: https://orcid.org/0000-0003-1106-9188, e-mail: milabudanovapskov@ mail.ru

\section{VLADIMIR.P. KRAMARENKO}

Immanuel Kant Baltic Federal University, Kaliningrad, Russian Federation ORCID: https://orcid.org/0000-0002-9662-0874, e-mail: vkram39@mail.ru

Abstract. The article investigates how the notion "execution of a sentence" was formed and analyzes the content of the stage of execution of a sentence as an independent part of criminal procedure, examines legal issues of criminal proceedings within the stage of execution of a sentence, and puts forward some ways to improve it. The fact 
that court activities aimed at considering and resolving issues related to the execution ofa sentence are defined as part of criminal procedurerather than as an independent stage is a subject for debate, because this activity may or may not take place. But we agree with those scholars who believe that the stage such as the presentation of a sentence for execution always emerges during sentencing, and the analogy with the stage of launching criminal investigation allows us to conclude that, that further criminal proceedings may occur several times or may not occur at all and thus form an independent stage of criminal procedure. We studiedthe opinions and statements of practitioners and scholars in the field of criminal procedure concerning the role and importance of criminal proceedings aimed at the execution of a sentence as an independent stage of criminal procedure, institution of criminal procedural law, a separate phase of criminal procedure and the theoretical arguments as to the essential nature and meaning of the execution of a sentence in criminal procedure. We conclude that criminal proceedings aimed at presenting the sentence for execution, consideration and resolution by the courtof the issues related to its executionform the content of an independent stage of criminal procedure, which has all the necessary and characteristic features.

Key words: execution of a sentence; stage of criminal procedure; subjects of execution of a sentence; criminal justice; criminal proceedings.

12.00.09 - Criminal procedure.

For citation: Shabanov V.B., Budanova L.Yu., Kramarenko V.P. Execution of a sentence - an independent stage of criminal proceedings. Penitentiary Science, 2020, vol. 14, no. 4 (52), pp. 560-565. DOI 10.46741/2686-9764-2020-14-4-560-565.

The key purposes of criminal procedure both in the Russian Federation and in the Republic of Belarus include protection of the rights and legitimate interests of persons and organizations who have been victims of crime, and protection ofan individual from unlawful and unjustified charges, convictions, and restrictions on their rights and freedoms [15, p. 130].

The sentence execution stage completes the activities of all participants in criminal procedure. We believe this stage is the final product of justice, which guarantees the restoration of violated rights and legitimate interests of individuals and organizations, as well as the implementation of the criminal policy of the state as a whole and the application of fair punishment to the guilty individual.

I.D. Perlov, dwelling upon the sentence, pointed out that it is passed in order to be executed; otherwise it loses its purpose. Moreover, if it will not be executed or executed ineffectively, then all activities aimed to solve the crime and expose the perpetrators, all the preliminary investigation and judicial review of criminal cases will be nullified [7, p. 54].

According to M.S. Strogovich, the entry of a sentence into legal force means that the sentence receives the validity of a law and is as binding as the law itself. The researcher also concludes that the execution of a sentence is the last stage of criminal procedure [11, p. 325].

Let us have a quick look into the history of formation of the institution of execution of a sentence as an independent stage of criminal procedure. For example, I.Ya. Foinitskii, defining the importance of implementing the principles of the administration of justice, in his writ- ings back in 1914 argued that the execution of a sentence is not only the implementation of the content of the latter, but also an act of judicial and punitive power, and is necessary in order to implement the principle of individualization of punishment. According to his viewpoint, the execution of a sentence as a stage requires certain elasticity and flexibility, and yet has to be based on the law and carried out under judicial control. The need for justice in the punitive activities of the state and the possibility to alter the sentence in the course of its execution led to the emergence of institutions such as judicial set-off in the punishment, conditional or unconditional release from punishment, respite of the sentence, and probation. I.Ya. Foinitskii argues that if the execution of a sentence did not have a proper impact on the convicted individual, then the court, on the basis of the law, has the right to replace the punishment with a more severe one - thus, the state's criminal policy will be implemented in full [13, p. 568-570].

A different position is presented in the works of V.K. Sluchevskii and N.N. Rozin: they believe that activities related to the execution of a sentence should be considered outside criminal procedure, because from the moment the sentence enters into legal force, the court's activity ends [10, p. 588-604, 646-656] and the work of institutions and bodies for the execution of the sentence begins [9, p. 518-520].

Current penal legislation of Russia and Belarus sees its main task in the protection of rights and freedoms and legitimate interests of convicts (Part 2 of Article 1 of Russia's Penal Enforcement Code, Part 1 of Article 2 of Belarus' Penal Enforcement Code). However, we 
note that convicts can implement some of their rights and legitimate interests only through penal institutions and bodies. For example, the implementation of the right of a convicted person to replace part of the unserved sentence with a more lenient one occurs only on the recommendation of a body or institution of the Federal Penitentiary Service of Russia (FSIN Russia), and such a recommendation is considered during the court session. V.L. Popov notes that such a procedure helps adjust punishments in order to achieve their main goal - to reform a convicted individual [8, p. 22-23].

It follows that the bodies executing criminal sanctions actuallyassess the ability to achieve the goals of the punishment imposed on the convict by the court in the course of their execution of the sentence and independently initiate the activity of the court aimed at reviewing and resolving questions about changing the order and conditions of serving it.

According to the study of scientists' opinions on the origin of criminal proceedings at the stage of execution of a sentence and its formation in an independent stage of criminal procedure, we can say that the criminal procedure status of institutions and bodies that execute sentences and enter into criminal procedure relations with the court regarding the execution of a sentence has not yet received effective legal regulation. This circumstance, in our opinion, is primarily due to the fact that there is an ongoing debate as to whether criminal proceedings in the execution of a sentence should be recognized as a stage of criminal procedure.

Our research shows that the first attempts at serious scientific substantiation of the essence of the stage of execution of a sentence and its place in the criminal justice system were made in the 1960s. This was due to the active reform of law enforcement legislation, which focused on the humanization of criminal procedure norms. This circumstance predetermined the formation of a traditional viewpoint concerning the execution of a sentence as a stage of criminal procedure. The emergence of this point of view, expressed by I.D. Perlov and E.F. Kutsova was logical, and it demonstrated perfectly the importance that should be attached to the act of execution of a court decision in a criminal case.

The stage of execution of a sentence, according to E.F. Kutsova, is the final stage of criminal procedure, because it consists of the activities of the court aimed at direct execution of the sentence, as well as due to the fact that only the court and no one else has the right to resolve all appeals of correctional bodies and institutions that are related to the execution of a sentence [4, p. 3-6].
Supporting the opinion that the execution of a sentence is an independent stage, I.D. Perlov provides the following arguments: first, this stage addresses its own independent tasks that differ significantly from the tasks of other stages; second, the composition of its actors is represented by a strictly defined circle of participants in criminal proceedings bound by specific criminal procedure relations typical of this very stage and taking place in special procedural forms; third, when making decisions, the court issues a legal act in the form of a ruling on issues that arise during the execution of the sentence and that are considered at the court session. In addition, I.D. Perlov argues that the execution of a sentence as an independent stage is a broader concept. One of the arguments in favor of such independence is that the execution of a sentence covers not only the procedural activity of the court, prosecutors, correctional institutions and non-governmental organizations, but also administrative and other activities of correctional institutions, the activities of nongovernmental organizations on reformation and rehabilitation of persons serving sentences for the crimes they committed; that is, the execution of a sentence is comprehensive in terms of legal regulation. Finally, according to I.D. Perlov, it is necessary to consider criminal procedure issues resolved at the stage of execution of a sentence in an organic combination with substantive law, which is also evidence of the independence of the latter [7, p. 3-6].

According to M.S. Strogovich, the execution of a sentence that has entered into legal force is the last stage of criminal procedure, in which its decisions are implemented. By this judicial act, the court that issued it not only confirms that the sentence has entered into legal force and is subject to execution, but also gives an order to relevant administrative bodies (correctional institution, etc.) on its actual execution [11, p. 424].

V.V. Nikolyuk in his works also touches upon the complexity of legal regulation, which is typical of the stage of execution of a sentence. We share his viewpoint, according to which this is due to the fact that along with the criminal procedure law, the issues regarding the execution of a sentence are governed by the relevant provisions of the Criminal Code of the Russian Federation (RF CC) and the Criminal Enforcement Code of the Russian Federation (RF CEC). Therefore, the independence of the institution of execution of the sentence as the final stage of criminal procedure, in his opinion, is characterized by the following indicators:

1) specific tasks that consist in presenting the sentence for execution and resolving all issues that arise in this case; 
2) a certain circle of participants in criminal proceedings defined by law, including bodies that execute punishments, between which specific criminal procedure relations are formed;

3) features of the procedural order, such as holding a fast-track court session, limited opportunities for appeal, etc.;

4) procedural decisions of the judge inherent in this stage of criminal procedure.

V.V. Nikolyuk believes that the activity of administrative bodies aimed at direct execution of sentences is included in the content of the stage of executionof the sentence [6, p. 3-5].

In the interpretation of T.S. Dvoryankina, author of Chapter 29 of the textbook on criminal procedure edited by P.A. Lupinskaya, the independence of the stage under consideration, in addition to the features defined by V.V. Nikoly$\mathrm{uk}$, is emphasized by the following points:

1) implementation of many tasks and principles of criminal procedure (adversarial nature of the process, the language of criminal procedure, respect of honor and dignity, protection of the rights and freedoms of man and citizen, free evaluation of the evidence, the right to appeal against procedural actions and decisions, inevitability of punishment);

2) the existence of its own circumstance in proof: it is not uniform and depends on the nature of the resolved issues, the range of which is quite varied; it occurs after the sentence comes into legal force upon its actual execution and, therefore, is determined by the norms of criminal, criminal-executive and criminal procedural law;

3 ) the execution of a sentence, unlike other stages of criminal procedure, where the initial and final moments and the sequence of procedural actions are clearly defined, is not a continuous stage [12, p. 869-871].

We agree with the opinion stated above, and we note that in some cases, for example, when the court directly executes a sentence, the initial and final moments of the execution stage have clearly defined boundaries associated with the proclamation of the sentence, which entails the immediate release of the defendant from custody.

Recognizing the independence of the stage of execution of a sentence, V.V. Vandyshev highlights a number of additional features, namely: besides the implementation of sentences, court decisions and rulings are also executed here; there is a possibility of multiple occurrence of criminal proceedings during the execution of a sentence; the court is exempt from performing control functions in relation to the previous stages of criminal procedure, etc. The author sees the significance of the stage in the implementation of the principle of inevitability of responsibility and punishment, ensuring the protection of the rights and legitimate interests of participants in criminal procedure, including those acquitted and convicted and their close relatives, providing educational and preventive influence on both participants in criminal procedure and other citizens [1].

A number of researchers, for example N.S. Manova, refer the execution of a sentence to the judicial stages of criminal procedure, noting that the subject of activity here is the court, but they do not include the activities of direct executors of court decisions in the content of the stage [5, p. 174].

We find it difficult to agree with this opinion on the grounds that, for example, at the initiative of the bodies executing the sentence, convicts, supervising prosecutors, and other subjects, the court considers and resolves a number of issues related to the execution of the sentence, therefore, the executors of court decisions participate in the court session and enter into criminal procedural legal relations.

The article cannot ignore the fact that after the introduction of the new criminal enforcement law, there was a rethinking of the provisions concerning the institution of execution of a sentence as a stage of criminal procedure. Changes in legislation and law enforcement practice have provided the ground for authors to avoid using the procedural category "stage" and applying it to the institution itself.

O.V. Volkolup, for example, wrote that "the execution of a sentence cannot be a stage of criminal procedure", and immediately, pointing to the activities of subjects to resolve issues arising during the execution of a sentence, suggested that it should be considered criminalprocedural. According to the researcher, in the framework of criminal procedure law there should be an institution of sentence enforcement that is used when the sentence execution is accompanied by a change in certain conditions of serving the court-appointed punishment, not associated with changes in the system of the established factual circumstances of the criminal case. In addition, in the opinion of O.V. Volkolup, if a situation arises when the initiation of a criminal case is denied, the appeal of the decision is carried out outside of any stage of criminal procedure [2, p. 208].

In the works of E.N. Gaponov, the idea prevails that judicial activity in the execution of a sentence has features that are expressed in the originality and relative independence from the bulk of criminal procedure, the subject of which is a criminal case. Judicial proceedings carried out in the framework of execution of a sentence are separate from criminal proceed- 
ings and cannot be considered a stage of criminal procedure. The opinion expressed by the researcher on the fact that with the development of criminal, criminal procedure and criminal enforcement legislation in domestic law, there emerges a platform for the formation of relatively independent legal procedure for the execution of a sentence [3, p. 13], can become an occasion for theoretical discussions and requires verification by practice.

We can draw a number of conclusions on the basis of our study of the statements of practitioners and academics in the field of criminal procedure concerning the role and importance of criminal procedure for the execution of a sentence as an independent stage of criminal procedure, institution of criminal procedure law, a separate phase of criminal proceedings and the provisions based on theoretical arguments as to the essential nature or meaning of the execution of a sentence in criminal procedure.

In particular, we believe that criminal proceedings aimed at presenting a sentence for execution, consideration and resolution of issues related to its execution by the court, is the content of an independent stage of criminal procedure, which has all the necessary and characteristic features that define it as such.

First, the stage of execution of a sentence, like any independent stage of criminal procedure, has its own goals and special range of permissible tasks that derive from the general purpose of criminal procedure and consist in protecting the rights and legitimate interests of individuals and organizations that are victims of crimes, and in protecting the convicted individual from the limitation of their rights and freedoms; the tasks are based on the activities performed at this stage, the content of which is the presentation of the sentence for execution, the consideration and resolution by the court of issues related to the execution of a sentence, as well as the court's implementation of control over the legality, timeliness and accuracy of the execution of the court-imposed sentence by the bodies and institutions authorized by the current legislation.

Second, the beginning of the stage is due to the entry into force of the sentence, ruling or resolution, followed by the mandatory stage of presenting the sentence for execution.

Further, the activities are implemented that go beyond criminal procedure and are regulated by penal enforcement legislation; such activities include actual execution of the sentence.

The stage of consideration and resolution by the court of issues related to the execution of a sentence takes place if it is necessary for the court to resolve issues provided for in Article 397 of RF CPC.

The stage of execution of a sentence is ended when the institution or body entrusted with the execution of punishment notifies the court that found the defendant guilty about the execution of the sentence.

In some cases, the beginning of the execution stage is the moment when the court announces the sentence, entailing the immediate release of the defendant from custody.

Third, at the stage of execution of a sentence, there is a special subject of proof - the circumstances to be established for each issue regulated by Article 397 of RF CPC.

Fourth, the circle of participants in criminal proceedings is typical only of this stage and is outlined by law: the court, the prosecutor, the defendant, the lawyer, the victim, representatives of the bodies executing punishments, the civil plaintiff, and the civil defendant. Let us note that at this stage not all subjects are granted the status of a participant in criminal procedure, although they enter into criminal procedural legal relations.

Fifth, at the stage of execution of a sentence, the activities of subjects entering into criminal procedural legal relations that are inherent only to this stage are carried out. The essence of these activities consists not only in presenting the court sentence for execution, but also in carrying out court sessions on issues related to the execution of the sentence, in accordance with Article 399 of RF CPC regulating a special procedure of court session on consideration and resolution of issues which have been the subject of judicial investigation. The stage of execution of a sentence consists of two phases: presentation of the sentence for execution, which is mandatory for each sentence, decision or ruling of the court, and the phase of consideration and resolution by the court of the issues provided for in Article 397 of RF CPC.

Sixth, the completion of the stage of execution of the sentence is accompanied by a mandatory turnover of the following procedural documents: notification of the penal institution or body on sending the copy of the court sentence, the decision of the court on issues related to the execution of the sentence, notification of the court that found the defendant guilty about the execution of the sentence by the penal institution or body, presentation of the penal institution and body on issues related to the execution of the sentence, the motion of the convict [14, p. 88].

Recognizing the execution of a sentence as an independent stage of criminal procedure, we 
understand that not all issues related to it are currently resolved to the extent that satisfies science and practice. We believe it is still necessary to conduct painstaking studies of the regulation of the procedure and terms of the court session on issues related to the execution of sentences; the criminal procedure status of subjects participating in the consideration and resolution by the court of issues arising during the execution of a sentence, including the consolidation of the criminal procedure status of penal institutions and bodies represented by their authorized staff, and the procedural form of documents that are being compiled at this stage [16, p. 387].

The legislative consolidation of the powers of penal institutions and bodies at the stage of execution of the sentence will make it possible to balance the rights and obligations of these subjects relative to other participants. To date, in accordance with the criminal procedure law, they cannot be referred to any of the existing categories of participants, and therefore it seems appropriate to supplement the latter. We note that in addition to institutions and bodies that execute sentences, none of the existing categories of participants in criminal procedure can be defined as a subject of criminal procedure known as an applicant. In order to achieve criminal procedure goals it is necessary to introduce a new category of "participants who make independent (own) claims". These subjects do not always act on the side of the prosecution or the defense and, unlike other participants, pursue their own goals in criminal procedure. Thus, we propose to supplement the Criminal Procedure Code of the Russian Federation with Chapter 8.1 "Participants in criminal procedure who make independent (own) claims".

\section{REFERENCES}

1. Vandyshev V.V. Ugolovnyi protsess. Obshchaya i Osobennaya chasti [Criminal procedure. The General part and the Special part]. Moscow: Volters Kluver, 2010. 720 p.

2. Volkolup O.V. Sistema ugolovnogo sudoproizvodstva i problemy ee sovershenstvovaniya: monografiya [Criminal justice system and problems of its improvement: monograph]. Saint Petersburg: Yurid. tsentr press, 2003.265 p.

3. Gaponov E.N. Sovershenstvovanie pravovogo regulirovaniya sudoproizvodstva pri ispolnenii prigovora: avtoreferat dissertatsii na soiskanie uchenoi stepeni kandidata yuridicheskikh nauk [Improvement of legal regulation of legal procedure in the execution of the sentence: Candidate of Sciences (Law) dissertation abstract]. Moscow, 2009.27 p.

4. Kutsova E.F. Ispolnenie prigovora: lektsii [Execution of a sentence: lectures]. Moscow:Yuridicheskaya literatura, 1960.66 p. 5. Manova N.S. Ugolovnyi protsess: uchebnoe posobie dlya vuzov [Criminal procedure: textbook for universities]. Moscow: Yurait, 2019. $221 \mathrm{p}$

6. Nikolyuk V.V. Ispolnenie prigovora: lektsiya [Execution of a sentence: lecture]. Omsk: Yuridicheskii institut MVD Rossii, 1988. 35 p.

7. Perlov N.I. Ispolnenie prigovora $v$ sovetskom ugolovnom protsesse: uchebnoe posobie [Execution of a sentence in the Soviet criminal process: textbook]. Moscow: Yuridicheskaya literatura, 1963. 227 p.

8. Popov V.L. The sentence as a separate stage of criminal justice. Vestnik Kaliningradskogo filiala Sankt-Peterburgskogo universiteta MVD Rossii = Bulletin of the Kaliningrad Branch of the SaintPetersburgUniversity of the Ministry of the Interior of Russia, 2017, no. 4 (50), pp. 22-24. (In Russ.).

9. Rozin N.N. Ugolovnoe sudoproizvodstvo: posobie k lektsiyam [Criminal proceedings: a guide to lectures]. Saint Petersburg: Pravo, 1914. 548 p.

10. Sluchevskii V. Uchebnik russkogo ugolovnogo protsessa. Sudoustroistvo - sudoproizvodstvo [Textbook of Russian criminal procedure. Judicial system - legal proceedings]. Saint Petersburg: Tip. M.M. Stasyulevicha, 1913.684 p.

11. Strogovich M.S. Kurs sovetskogo ugolovnogo protsessa. V 2 tomakh. Tom 2. Poryadok proizvodstva po ugolovnym delam po sovetskomu ugolovno-protsessual'nomu pravu [A course in the Soviet criminal procedure. In 2 volumes. Volume 2. Procedure for criminal cases in the Soviet criminal procedure law]. Moscow: Nauka, 1970. 616 p.

12. LupinskayaP.A. (Ed.). Ugolovno-protsessual'noe pravo Rossiiskoi Federatsii: uchebnik [Criminal procedure law of the Russian Federation: textbook]. Moscow: NORMA: INFRA M, 2011. 1088 p.

13. Foinitskii I.Ya. Kurs ugolovnogo sudoproizvodstva. V 2 tomakh [A course in criminal proceedings. In 2 volumes]. Volume 2. Saint Petersburg: Al'fa, 1996. 607 p.

14. Shabanov V.B.,Budanova L.Yu., Aleksandrova O.P. The concept and meaning of criminal procedure activities of bodies executing punishments at the stage of execution of the sentence. Vestnik Samarskogo instituta FSIN Rossii = Bulletin of the Samara Law Institute, 2019, no. 4, pp. 86-91. (In Russian).

15. Shcherbakov A.V., Mikhailova O.E., Uskacheva I.B., Bogdanov M.N., Shatov S.A. Foreign experience in ensuring the security of the penitentiary system and the possibility of its use in domestic practice. Janus.net, 2018, vol. 9, no. 1, pp. 122-136.

16. Shcherbakov A.V., Smirnova I.N., Budanova L.Y., Shabanov V.B. International legal acts in the field of security and their implementation in the penal system of Russia. Journal of Advanced Research in Dynamical and Control Systems, 2020, vol. 12, no. 2 (Special Issue), pp. 387-390.

\section{INFORMATION ABOUT THE AUTHORS}

VYACHESLAV B. SHABANOV - Doctor of Sciences (Law), Professor, head of the Department of Criminalistics at the Legal Faculty, Belarusian State University, Minsk, Republic of Belarus. ORCID: https://orcid.org/0000-0002-5796-3727, e-mail: lawcrim@bsu.by

LYUDMILA YU. BUDANOVA - Candidate of Sciences (Law), senior lecturer at the Department of Organizing the Regime and Intelligence-Gathering Activities in the Penal System, Pskov Branch of the Academy of FSIN Russia, Pskov, Russian Federation. ORCID: https://orcid.org/0000-0003-1106-9188, e-mail: milabudanovapskov@mail.ru

VLADIMIR. P. KRAMARENKO - Candidate of Sciences (Law), Associate Professor, associate professor of the Department of Criminal Procedure, Criminalistics and Legal Informatics at the Law Institute, Immanuel Kant Baltic Federal University, Kaliningrad, Russian Federation. ORCID: https://orcid.org/0000-0002-9662-0874, e-mail: vkram39@mail.ru 